\title{
Intervensi Nyeri Punggung pada Ibu Hamil di Desa Pengelatan
}

\author{
Wigutomo Gozali $^{*}$, Nyoman Ayu Dwi Astini², M Rizal Permadi ${ }^{3}$ iD \\ 1,2,3 Jurusan D3 Kebidanan Fakultas Olahraga dan Kesehatan Universitas Pendidikan Ganesha Program Studi D4 Gizi \\ Klinik Politeknik Negeri Jember \\ *Corresponding author:w22gozali@gmail.com
}

\begin{abstract}
Pembesaran uterus dan penambahan berat badan pada kehamilan Trimester III maka pusat gravitasi berpindah ke depan sehingga ibu hamil harus menyesuaikan berdirinya. Perubahan tubuh yang tidak tepat akan memaksa peregangan tambahan dan kelelahan pada tubuh terutama pada daerah punggung belakang. Penyebab nyeri punggung bawah salah satunya adalah karena perubahan hormonal yang menimbulkan perubahan pada jaringan lunak penyangga dan penghubung sehingga menurunnya elastisitas dan fleksibilitas otot. Dampak negatif yang ditimbulkan nyeri punggung bawah yaitu dapat menimbulkan menurunnya kualitas hidup ibu hamil karena terganggunya aktivitas fisik sehari-hari. Tujuan penelitian untuk mengetahui intensitas nyeri sebelum dan sesudah dilakukan intervensi nyeri punggung pada ibu hamil trimester II dan III di Desa Pengelatan, Kecamatan Buleleng, Kabupaten Buleleng. Penelitian ini merupakan penelitian pra-eksperimen dengan rancangan "One Group Pretest-Postest". Metode pengambilan sampel yang digunakan total sampling. Metode pengumpulan data yang digunakan wawancara, observasi, intervensi dan skala nyeri Visual Analog Scale ( VAS). Metode analisis data digunakan univariate dan analisis bevariate menggunakan uji t berpasangan (paired t-test). Hasil penelitian ada perbedaan intensitas nyeri sebelum dan sesudah responden di intervensi massage. Hendaknya pada ibu hamil rutin dilakukan terapi massage untuk mengurangi nyeri.
\end{abstract}

Keywords: Ibu Hamil, Nyeri Punggung, Pijat.

\section{Abstract}

The enlargement of the uterus and weight gain in the third trimester of pregnancy then the center of gravity moves forward so that the pregnant woman must adjust her stance. Improper body changes will force additional stretching and fatigue on the body, especially in the back. One of the causes of low back pain is due to hormonal changes that cause changes in the supporting and connecting soft tissues resulting in decreased muscle elasticity and flexibility. The negative impact caused by low back pain is that it can cause a decrease in the quality of life of pregnant women due to disruption of daily physical activities. The research objective was to determine the intensity of pain before and after back pain intervention in two and third trimester pregnant women in Pengelatan Village, Buleleng District, Buleleng Regency. This research is a pre-experimental study with a "One Group Pretest-Postest" design. The sampling method used was total sampling. Data collection by interviews, observation, intervention and pain scale Visual Analog Scale (VAS). Analysis data using the univariate and bevariate analysis using paired t-test. The results of the study were differences in pain intensity before and after respondents in the massage intervention. Pregnant women should routinely do massage therapy to reduce pain.

Keywords: Pregnant Woman, Back Pain, Massage.

\section{Introduction}

Kehamilan merupakan suatu proses yang alami dan normal. Selama hamil seorang ibu mengalami perubahan- perubahan yang terjadi baik fisik maupun psikologis (Resmi et al., 2017; Sukeksi et al., 2018). Salah satu keluhan adalah nyeri punggung, nyeri punggung bawah pada ibu hamil trimester II dan III merupakan keluhan umum yang sering terjadi di kalangan ibu hamil, diperkirakan sekitar $70 \%$ wanita hamil mengeluhkan beberapa bentuk

$\begin{array}{ll}\text { History: } & \\ \text { Received } & : 10 \text { July } 2020 \\ \text { Revised } & : 09 \text { August } 2020 \\ \text { Accepted } & : 06 \text { Sepember } 2020 \\ \text { Published } & : 30 \text { October } 2020\end{array}$


nyeri punggung pada suatu saat dalam kehamilan, persalinan hingga postpartum (Purnamasari, 2019). Nyeri punggung biasanya akan meningkat intensitasnya seiring pertambahan usia kehamilan. Nyeri punggung saat kehamilan mencapai puncak pada minggu ke-24 sampai dengan minggu ke- 28, tepat sebelum pertumbuhan abdomen mencapai titik maksimum (Megasari, 2015).

Berdasarkan Profil Dinas Kesehatan Kabupaten (2018) jumlah ibu hamil di Kabupaten Buleleng sebanyak 11.126 orang, sedangkan di wilayah kerja Puskesmas Buleleng III terdapat ibu hamil 799 orang. Ibu hamil yang berkunjung kepalayanan kesehatan pada Trimester I (K1) 775 orang (97\%) dan kunjungan Trimester III (K4) 766 orang (96,2\%). Hasil survey mawas diri (SMD) praktik kerja lapangan mahasiswa kebidanan di Desa Pengelatan (2020), diperoleh data ibu hamil sebanyak 28 orang dengan usia kehamilan TM I. 2 orang, TM II. 15 orang, TM III. 11 orang. Berdasarkan hasil studi pendahuluan melalui wawancara pada ibu hamil (Trimester III) TM III yang datang berkunjung ke pelayanan kesehatan diperoleh sekitar 5 orang ibu mengalami nyeri punggung.

Penyebab nyeri punggung bawah salah satunya adalah karena perubahan hormonal yang menimbulkan perubahan pada jaringan lunak penyangga dan penghubung sehingga menurunnya elastisitas dan fleksibilitas otot (Lina, 2018; Wahyuni \& Eko, 2012). Nyeri punggung yang tidak segera diatasi berakibat nyeri punggung dalam jangka panjang, meningkatkan nyeri punggung pasca partum (Lilis, 2019; Rejeki \& Fitriani, 2019) dan nyeri punggung kronis yang akan lebih sulit diobati atau disembuhkan (Wahyuni et al., 2016).

Salah satu cara penanganan rasa nyeri pada ibu hamil trimester III adalah dengan memberikan terapi massage (pemijatan) sekitar punggung atas dan bawah, untuk memberikan rasa nyaman dan menurunkan intensitas nyeri. Massage merupakan suatu tindakan asuhan sayang ibu sehingga akan meningkatkan rasa aman, meningkatkan kualitas hidup terutama bagi ibu hamil (Rahayu, 2020). Massage dapat dilakukan dengan jumlah tekanan dan stimulasi yang bervariasi terhadap berbagai titik-titik pemicu myofascial di seluruh tubuh. Pijatan dapat merangsang tubuh untuk melepaskan senyawa endorfin yang merupakan pereda rasa sakit dan dapat menciptakan perasaan nyaman (Kartikasari \& Nuryanti, 2016). Beberapa penelitian yang dilakukan sebelumnya berkaitan dengan Massage.

Penelitian yang dilakukan oleh Diana, (2019) menunjukkan sebelum diberikan endorphin massage sebagian besar ibu yang mengalami nyeri punggung sedang sebanyak 12 orang $(60 \%)$. Setelah diberikan endorphin massage sebagian besar ibu mengalami nyeri punggung ringan yaitu 14 orang $(70 \%)$. Dari hasil analisis menggunakan uji Wilcoxon didapatkan nilai $\rho=0,000<\alpha=0,05$ yang menunjukkan bahwa ada keefektifan yang signifikan endorphin massage terhadap penurunan nyeri punggung ibu hamil trimester III di BPM Lulu Surabaya. Endorphin massage merupakan pilihan pengobatan non farmakologis yang bisa meringankan nyeri punggung ibu hamil trimester III. Sehingga bidan dapat melakukan pelayanan dengan memberikan asuhan kebidanan pada ibu hamil trimester III yang mengalami keluhan nyeri punggung dengan melakukan teknik endorphin massage. Penelitian yang dilakukan Prasetyorini \& Sukesi, (2018) menunjukkan bahwa pijat perineum bisa dijadikan intervensi keperawatan mandiri dalam menurunkan tingkat kecemasan pada ibu hamil trimester 3. Penelitian yang dilakukan oleh Yantina \& Evrianasari, (2020) menunjukkan bahwa Rata-rata skor kualitas tidur ibu hamil pada hasil pengukuran menggunakan kuesioner the Pittsburgh Sleep Quality Index (PSQI) sebelum (pretest) intervensi back massage adalah 6,281,461 dan setelah (post-test) intervensi back massage adalah 5,03?1,349 dengan selisih rata-rata 1,241?0,739. Pada hasil uji paired sample t test menunjukkan back massage terbukti berpengaruh terhadap kualitas tidur ibu hamil trimester III (p-value $0,000<0,05$ ).

Melihat potensi keadaan ibu hamil yang selama ini, terjadi keluhan pada punggung dan akan mengakibatkan terganggunya aktivitas ibu hamil dan janin selama periode 
kehamilan, urgensi penanganannya sesegera mungkin. Sehingga diharapkan melalui intervensi massage ini akan bermanfaat pada kesehatan ibu hamil dan janin untuk masa perkembangan kehamilannya. Selama ini ibu hamil TM III yang berkunjung di pos pelayanan terpadu (Posyandu) atau bidan praktik mandiri (BPM) di Desa Pengelatan, belum pernah dilakukan intervensi massage untuk mengatasi rasa nyeri pada punggung ibu. Melihat permasalahan maka dirumuskan tujuan penelitian yaitu mengkaji intervensi nyeri punggung pada ibu hamil TM III di Desa Pengelatan.

\section{Materials and Methods}

Jenis penelitian ini adalah pra-eksperimen dengan rancangan "One Group PretestPostest". Rancangan ini juga tidak ada kelompok pembanding (kontrol), karena sebelumnya telah dilakukan observasi pertama melalui pengukuran skala nyeri (VAS) kemudian memberikan intervensi/perlakuan, dan mencatat perubahan-perubahan yang terjadi setelah adanya perlakuan. (Notoatmodjo, 2010). Bentuk perlakuan terhadap subyek secara individual, pada ibu hamil trimester II dan III berupa massage punggungPenelitian ini dilakukan di Desa Pengelatan Kecamatan Buleleng, Kabupaten Buleleng. Populasi penelitian ini adalah seluruh ibu hamil trimester III yang berada di Desa Penglematan. Teknik sampling yang digunakan pada penelitian ini adalah Nonprobability Sampling yaitu Total Sampling. Total sampling adalah teknik penentuan sampel bila semua anggota populasi digunakan sebagai sampel atau responden. Seluruh ibu hamil trimester II dan III di Desa Pengelatan sebanyak 30 orang menjadi sampel atau responden pada penelitian ini. Data yang diambil yaitu umur, tingkat pendidikan, paritas, usia kehamilan, pekerjaan dan itensitas nyeri punggung.

\section{Results and Discussion}

Dari 30 responden sebagian besar berumur 20-30 tahun yaitu sebanyak 26 orang (86\%), 20 tahun 2 orang (7\%) dan lebih dari 35 tahun 2 orang (7\%). Berdasarkan tingkat pendidikan sebagian besar berpendidikan SMA/SMK sebanyak 22 orang (73\%). sedangkan yang berpendidikan SMP 6 orang (20\%) dan 2 orang berpendidikan Akademi/Perguruan Tinggi. Paritas ibu hamil Multipara sebanyak 21 orang $(70 \%)$, sedangkan yang primipara terdapat 9 orang (30\%). Usia kehamilan yang terbanyak 28-40 minggu sebanyak 27 orang (90\%), usia kehamilan 12- 28 minggu sebanyak 3 orang (10\%) dan usia kehamilan 0-12 minggu tidak ditemukan setelah dilakukan pmeriksaan awal. Pekerjaan ibu hamil sebanyak 27 orang 90\%, pekerjaan lainnya seperti dagang sebanyak 2orang (7\%), pekerjaan ibu hamil sebagai petani 1 orang $(3 \%)$. Itensitas nyeri sebelum dilakukan intervensi dengan katagori nyeri berat 1 orang (3\%), nyeri sedang 17 orang (57\%), nyeri ringan 9 orang (30\%), tidak mengalami nyeri 3 orang (10\%). Internsitas nyeri setelah dilakukan intervensi dengan katagori nyeri ringan 12 orang (40\%) dan tidak nyeri sebanyak 18 orang (60\%). Jadi Terdapat perbedaan intensitas nyeri pada ibu hamil TM III sebelum dan sesudah responden di intervensi massage.

Massage adalah melakukan tekanan tangan jaringan lunak, biasanya otot, tendon, atau ligamentum, tanpa menyebabkan gerakan atau perubahan posisi sendi untuk meredakan nyeri, menghasilkan relaksasi, dan/ atau memperbaiki sirkulasi (Astarani \& Radita, 2015; Komang, 2017). Massage merupakan suatu tindakan asuhan sayang ibu sehingga akan meningkatkan rasa aman, meningkatkan kualitas hidup terutama bagi ibu hamil (Rahayu, 2020). Massage dapat dilakukan dengan jumlah tekanan dan stimulasi yang bervariasi terhadap berbagai titik-titik pemicu miofasial di seluruh tubuh. Pijatan dapat merangsang tubuh untuk melepaskan senyawa endorfin yang merupakan pereda rasa sakit dan dapat menciptakan perasaan nyaman (Kartikasari \& Nuryanti, 2016). Cara massage adalah tindakan 
keperawatan dengan caramem berikan massage pada klien dalam memenuhi kebutuhan rasanyaman (nyeri) pada daerah superfisial atau pada otot/tulang. Tindakan massage ini hanya untuk mengurangirangsangan nyeri akibat terganggunaya sirkulasi (Hidayat, 2005). Umur 20-35 tahun merupakan kelompok umur kesehatan reproduksi yang optimal (Winkjosastro, 2012). Respon terhadap nyeri punggung TM III berbeda setiap orang, karena adaptasi yang digunakan berbeda sesuai dengan tingkat pendidikan, semakin individu tersebut tidak memiliki koping yang bagus terhadap penyelesaian masalah, maka akan menimbulkan stress dan berakibat pada kontraksi uterus yang tidak adekuat (Wahyuni \& Wahyuningsih, 2015). Berdasarkan jabaran tersebut dapat dikatakan bahwa massage dapat mengurangi nyeri punggung.

Nyeri punggung bagian atas maupun bawah yang dialami ibu hamil sering dikeluhkan terutama menginjak trimester III, karena terjadi peningkatan lordosis atau tulang punggung melengkung. Hal ini menyebabkan pergseran pada pusat keseimbangan badan yang bergeser maju searah dengan tulang belakang dan karena beban rahim berada di atas daerah pelvis, menyebabkan pelvis bergeser kedepan sehingga pinggang menjadi semakin melengkung. Keadaaan ini dapat menyebabkan nyeri pinggang. Nyeri punggung bawah pada ibu hamil trimester II dan III merupakan keluhan umum yang sering terjadi di kalangan ibu hamil, diperkirakan sekitar 70\% wanita hamil mengeluhkan beberapa bentuk nyeri punggung pada suatu saat dalam kehamilan, persalinan hingga postpartum (Purnamasari, 2019). Nyeri punggung biasanya akan meningkat intensitasnya seiring pertambahan usia kehamilan. Nyeri pungung saat kehamilan mencapai puncak pada minggu ke-24 sampai dengan minggu ke- 28 , tepat sebelum pertumbuhan abdomen mencapai titik maksimum (Megasari, 2015).

Hasil penelitian ini didukung oleh Penelitian yang dilakukan oleh Diana, (2019) menunjukkan sebelum diberikan endorphin massage sebagian besar ibu yang mengalami nyeri punggung sedang sebanyak 12 orang (60\%). Setelah diberikan endorphin massage sebagian besar ibu mengalami nyeri punggung ringan yaitu 14 orang (70\%). Dari hasil analisis menggunakan uji Wilcoxon didapatkan nilai $\rho=0,000<\alpha=0,05$ yang menunjukkan bahwa ada keefektifan yang sifnifikan endorphin massage terhadap penurunan nyeri punggung ibu hamil trimester III di BPM Lulu Surabaya. Endorphin massage merupakan pilihan pengobatan non famakologis yang bisa meringankan nyeri punggung ibu hamil trimester III. Sehingga bidan dapat melakukan pelayanan dengan memberikan asuhan kebidanan pada ibu hamil trimester III yang mengalami keluhan nyeri punggung dengan melakukan teknik endorphin massage. Penelitian yang dilakukan Prasetyorini \& Sukesi, (2018) menunjukkan bahwa pijat perineum bisa dijadikan intervensi keperawatan mandiri dalam menurunkan tingkat kecemasan pada ibu hamil trimester 3. Penelitian yang dilakukan oleh Yantina \& Evrianasari, (2020) menunjukkan bahwa Rata-rata skor kualitas tidur ibu hamil pada hasil pengukuran menggunakan kuesioner the Pittsburgh Sleep Quality Index (PSQI) sebelum (pretest) intervensi back massage adalah 6,281,461 dan setelah (post-test) intervensi back massage adalah 5,03?1,349 dengan selisih rata-rata 1,241?0,739. Pada hasil uji paired sample $t$ test menunjukkan back massage terbukti berpengaruh terhadap kualitas tidur ibu hamil trimester III ( $\mathrm{p}$-value $0,000<0,05$ ).

\section{Conclusion}

Berdasarkan hasil penelitian dapat disimpulkan sebagai berikut: 1) sebagian besar berumur 25-35 tahun, pendidikan terbanyak SMA, paritas sebagian besar multipara, usia kehamilan 28-40 minggu dan sebagian ibu hamil TM III tidak bekerja 2) Sebelum dilakukan intervensi massage pada ibu hamil TM III sesuai dengan pengukuran skala VAS terdapat ibu hamil mengalami nyeri sedang 57\%. 3) Setelah dilakukan intervensi massage pada ibu hamil TM III sesuai dengan pengukuran skala VAS ibu hamil tidak nyeri $60 \%$ dan nyeri dalam kategori ringan $40 \%$. 4) . Terdapat perbedaan intensitas nyeri pada ibu hamil TM III 
sebelum dan sesudah responden di intervensi massage. Perlu penelitian lebih lanjut mengenai faktor-faktor yang mempengaruhi nyeri pada ibu hamil. Sebaiknya pada ibu hamil rutin dilakukan terapi massage untuk mengurangi nyeri.

\section{References}

Astarani, K., \& Radita, F. B. (2015). Terapi Back Massage Menurunkan Nyeri Pada Pasien Post Operasi Abdomen. Jurnal Penelitian Keperawatan, 1(2), 196-204.

Diana, W. (2019). Endorphin Massage Efektif Menurunkan Nyeri Punggung Ibu Hamil Trimester Iii. Journal of Health Sciences, 12(02), 62-70. https://doi.org/10.33086/jhs.v12i02.1128

Kartikasari, R. I., \& Nuryanti, A. (2016). Pengaruh Endorphin Massege Terhadap Penurunan Inensitas Nyeri Punggung Ibu Hamil. Rakernas Aipkema 2016, 1, 297-304.

Komang, A. T. W. (2017). Teknik Massage Effleurage pada Ekstremitas Inferior Sebagai Pemulihan Pasif dalam Meningkatkan Kelincahan. Jurnal Pendidikan Kesehatan Rekreasi, 1, 1-9.

Lilis, D. N. (2019). Pengaruh Senam Hamil Terhadap Nyeri Punggung Bawah Pada Ibu Hamil Trimester III The Effect Of Gymnastics on Lower Back Pain Among Pregnant Women Trimester III. Journal Health \& Science: Gorontalo Journal Health and Science Community, 3(2), 40-45. http://ejurnal.ung.ac.id/index.php/gojhes/article/view/2714

Lina, F. (2018). Efektivitas Senam Hamil dan Yoga Hamil Terhadap Penurunan Nyeri Punggung pada Ibu Hamil Trimester III di Puskemas Pekkabata. Jurnal Kesehatan Masyarakat Polewali, 4(2). https://media.neliti.com/media/publications/283679.pdf

Megasari, M. (2015). Hubungan Senam Hamil dengan Nyeri Punggung Pada Ibu Hamil Trimester III. Jurnal Kesehatan Komunitas, 3(1), 17-20. https://doi.org/10.25311/jkk.vol3.iss1.95

Prasetyorini, H., \& Sukesi, N. (2018). Pengaruh Pijat Perineum Terhadap Tingkat Kecemasan Ibu Trimester III Di Puskesmas Manyaran. Jurnal Ilmu Keperawatan Maternitas, 1(1), 26. https://doi.org/10.32584/jikm.v1i1.106

Purnamasari, K. D. (2019). Nyeri Punggung Bawah Pada Ibu Hamil Trimester Ii Dan Iii. Journal of Midwifery and Public Health, 1(1), 9. https://doi.org/10.25157/jmph.v1i1.2000

Rahayu, D. E. (2020). Pelaksanaan Massage Punggung Dengan Minyak Kenanga Pada Ibu Hamil Trimester III. Journal of Community Engagement in Health, 3(2), 349-352. https://doi.org/https://doi.org/10.30994/jceh.v3i2.96

Rejeki, S. T., \& Fitriani, Y. (2019). Pengaruh Yoga Prenatal terhadap Nyeri Punggung pada Ibu Hamil Trimester II dan III di Lia Azzahra Mom \& Baby Spa Tegal. Jurnal Kebidanan, $3(2)$ $67-72$. https://ejr.stikesmuhkudus.ac.id/index.php/ijb/article/download/756/452

Resmi, D. C., Saputro, S. H., \& Runjati. (2017). Pengaruh Yoga Terhadap Nyeri Punggung Bawah Pada Ibu Hamil Trimester III Di Puskesmas Kalikajar I Kabupaten Wonosobo. Jurnal Ilmiah Kesehatan, 8(1), 1-10.

Sukeksi, N. T., Kostania, G., \& Suryani, E. (2018). Pengaruh Teknik Akupressure Terhadap Nyeri Punggung Pada Ibu Hamil Di Wilayah Puskesmas Jogonalan I Klaten. Jurnal 
Kebidanan Dan Kesehatan Tradisional, $\quad 3(1), \quad$ 1-7. https://doi.org/10.37341/jkkt.v3i1.61

Wahyuni, \& Eko, P. (2012). Manfaat Kinesiotapping Untuk Mengurangi Nyeri Punggung Bawah Pada Kehamilan Trimester Ke III. Jurnal Kesehatan, 5(2), 119-129. https://publikasiilmiah.ums.ac.id/handle/11617/3281?show=full

Wahyuni, S., Raden, A., \& Evi, N. (2016). Perbandingan Trancutaneous Electrical Nerve Stimulation Dan Kinesio Taping Terhadap Penurunan. Perbandingan Trancutaneous Electrical Nerve Stimulation Dan Kinesio Taping Terhadap Penurunan Skala Nyeri Punggung Bawah Pada Ibu Hamil Trimester Iii Di Puskesmas Juwiring Kabupaten Klaten, 11, 14.

Wahyuni, S., \& Wahyuningsih, E. (2015). Pengaruh massage effleurage terhadap tingkat nyeri persalinan kala I fase aktif pada ibu bersalin di RSU PKU Muhammadiyah Delanggu Klaten 2015. Jurnal Involusi Kebeidanan, 5(10), 43-53.

Winkjosastro, H. (2012). Ilmu Bedah Kebidanan. Yayasan Bina Pustaka Sawono Prawirohardjo.

Yantina, Y., \& Evrianasari, N. (2020). Back Massage Pada Kualitas Tidur Ibu Hamil Trimester Iii. Jurnal Kebidanan Malahayati, 6(4), 408-412. https://doi.org/10.33024/jkm.v6i4.3281 